\title{
Learning Design Based on Local Wisdom Maddawa-dawa, Mammanu-manu and Mappettuada
}

\author{
A. Nurannisa F. A ${ }^{1}$, Andi Muhammad Irfan Taufan Asfar ${ }^{2,3}$, Andi Muhamad Iqbal Akbar Asfar ${ }^{3}$ \\ 1,2Department of Mathematics Education, STKIP Muhammadiyah Bone, Indonesia \\ 3Doctoral Program of Educational Science, State of Makassar University, Indonesia \\ 1andinurannisa30@gmail.com, ${ }^{2}$ tauvanlewis00@gmail.com, ${ }^{3}$ andiifalasfar@gmail.com
}

\begin{tabular}{|c|c|}
\hline & ABSTRACT \\
\hline Article History: & \multirow{10}{*}{$\begin{array}{l}\text { Local traditions of Maddawa-dawa, Mammanu-manu, Mapppettuada as a form of } \\
\text { local wisdom that elaborated entry into learning, especially mathematics. In its } \\
\text { application the local traditions of Maddawa-dawa, Mammanu-manu, } \\
\text { Mapppettuada integrated with an android application, namely the application of } \\
\text { group maker is used on the phase Maddawa-dawa, application lucky wheel and } \\
\text { mind mapping is used on the phase Mammanu-manu and application pro \& cons } \\
\text { used on the phase Mappettuada. This research emphasizes the design process } \\
\text { with a focus on the literature review in finding the proper integration between } \\
\text { local traditions of Maddawa-dawa, Mammanu-manu, Mapppettuada with android } \\
\text { apps that are focused student-centered in learning. The results of this design are } \\
\text { expected to provide an alternative solution in improving the ability of } \\
\text { extrapolation of the students especially in the learning of mathematics through } \\
\text { the approach of local traditions in the learning process. }\end{array}$} \\
\hline ceived : 0 & \\
\hline Revised : 16 & \\
\hline Accepted : 17 & \\
\hline Online & \\
\hline Keyword: & \\
\hline tion ability; & \\
\hline $\begin{array}{l}\text { Maddawa-dawa; } \\
\text { Maтmanu-manu; }\end{array}$ & \\
\hline Mappettuada. & \\
\hline & \\
\hline
\end{tabular}

\section{A. INTRODUCTION}

Mathematics is one of the subjects that are the main concern and has a major influence in everyday life (Nuraini, 2018). However, many students fear mathematics because it is considered complicated to understand and understand (Asfar, Asfar, Aspikal \& Nurwijaya, 2019). In fact, learning mathematics can train students to understand a concept through thinking and reasoning to conclude, develop student creativity, make predictions or guesses, develop problem-solving skills and convey information and communicate ideas (Nugraha \& Octavianah, 2020).

The importance of learning mathematics above is not accompanied by the mathematical abilities of the students. Several facts in the field show that the mathematical ability of Indonesian students is still very low, seen from the results of the survey results Program for International Student Assessment (PISA) 2018 (OECD, 2019) that the mathematics learning achievement of Indonesian students reaches an average score of 379 which is ranked 67 out of 73 countries. This is in line with the results survey Trends International Mathematics and Science Study (TIMSS) of 2015, where Indonesia was ranked 44th out of 49 countries with an average score of 397 (IEA, 2016). In addition, the results of the 2017 Indonesian Student 
Competency Assessment (ISCA) showed that the lowest score in mathematics was 0.93 and the highest score was only 67.39 with a mean score of 27.51 (Kemdikbud, 2019a). Likewise, the results of the 2019 National Examination (NE) for Indonesian students for junior high school level obtained an average math score of 46.56 (Kemdikbud, 2019b). It is feared that the low mathematical ability of Indonesian students will have an impact on the competitiveness of students in the era of the Industrial Revolution 4.0.

One of the factors that causes the low mathematical ability of Indonesian students is the lack of understanding of students' mathematical concepts, especially the extrapolation level, where mathematics is concerned with abstract and hierarchical concepts, so that in learning mathematics no conceptual stages should be missed (Asfar, Asfar, Darnawati \& Darmawan, 2019). A hierarchical mathematical concept requires students to be able to predict the tendency (extrapolation) of a mathematical problem (Rohaeti \& Bernard, 2018). However, Effendi (2018) research results show that most students still find it difficult to extrapolate from solving mathematical problems at hand.

The ability to extrapolate (extrapolation) is to apply concepts in mathematical calculations (Rahayu \& Pujiastuti, 2018) to see the trend or direction of the continuation of a finding (Syarifah, 2017). Students are expected to be able to see behind what is written, make predictions about consequences, and expand perceptions in terms of time, dimensions, cases, or problems through extrapolation abilities (Suhardi, 2018). The low ability of students to extrapolate can be influenced by the lack of giving questions that stimulate students' thinking processes, not linking concepts to real-life (Sutisna, Maulana \& Subarjah, 2016), and only providing practice questions by utilizing existing LKS (Aryani, Marzuki \& Suryani, 2019). Besides, the mathematics learning process in schools still tends to be teacher centered, where students just listen, pay attention, take notes, then work on practice questions and seem passive (Asfar, Asfar \& Sartina, 2018; Azis et al., 2019). Learning like this does not provide opportunities for students to be directly involved in suggesting ideas and that will lead to the formation of their mathematical knowledge (Asfar, Nur \& Asfar, 2019; Nur, Asfar, Ruhni \& Nurliah, 2019).

The problem above is in line with the information obtained during the implementation of apprenticeship 2 in class VIII SMP Negeri $1 \mathrm{Kahu}$, Kahu District, Bone Regency, South Sulawesi, that the extrapolation ability of students in mathematics is still low. Students seem to be less able to apply concepts in mathematical calculations, marked by the inability of students to solve math problems with a different form of questions than before. Besides, students also experience difficulties in predicting trends that will occur, interpreting the meaning of mathematical concepts, and concluding solutions to problems given. As a result, students are unable to solve math problems at a higher level because it is difficult to understand the previous material even though the teacher has made perceptions.

One of the efforts that can be made to overcome the above problems while improving students' extrapolation abilities is by involving socio-cultural factors that have positive values for educational practice in learning (Majid 2019). Maddawa-dawa, Mammanu-manu ' and Mappettuada are traditions of the Bugis-Makassar tribe student-centered so they can be used as methods in the learning process. In addition, the use of android in the learning process can overcome student boredom, so that learning can take place effectively and increase students' interest in learning mathematics (Zakiy, Syazali \& Farida, 2018). Some android applications that can be applied to the traditions of the Bugis-Makassar Maddawa-dawa, Mammanu-manu, Mappettuada are applications group maker at the Maddawa-dawa phase, lucky wheel and mind mapping at the Mammanu-manu phase as well as applications pro \& cons at the Mappettuada phase. Therefore, this study discusses a technology-integrated local wisdom-based learning design for students' extrapolation abilities. 


\section{B. METHODS}

The research method used is a qualitative paradigm with descriptive methods, namely the form of exposure based on literature review and the results of other supporting sources. The purpose of this study is to design a technology-integrated local wisdom-based learning process, in this case the use of an android application in order to design learning in the form of ethnopedagogy that is focused on extrapolated abilities. The design procedure used is data collection from various literatures in the form of articles, books and journals that touch on actual pedagogical issues in relation to research studies as a theoretical basis in making systematic syntax of learning. In measuring the success of the learning method, it refers to the extrapolation ability indicator with the scoring rubric in Table 1.

Table 1. Extrapolation Ability Scoring Rubric

\begin{tabular}{|c|c|c|c|}
\hline Indicator & $\begin{array}{l}\text { Question } \\
\text { Number }\end{array}$ & Score Assessment Criteria & Score \\
\hline $\begin{array}{l}\text { Predicting } \\
\text { trends that } \\
\text { will occur }\end{array}$ & $\begin{array}{c}1,2,3,4 \\
5\end{array}$ & $\begin{array}{l}\text { 1. Predict the overall trend correctly and completely } \\
\text { 2. Predicts a trend that will occur correctly but incompletely } \\
\text { 3. Predicts an impending trend complete but wrong answers } \\
\text { 4. Predicts the likely trend with wrong and incomplete } \\
\text { answers } \\
\text { 5. Wrong answer or no answer }\end{array}$ & $\begin{array}{l}4 \\
3 \\
2 \\
1 \\
0\end{array}$ \\
\hline $\begin{array}{l}\text { Interpreting } \\
\text { the meaning } \\
\text { of } \\
\text { mathematical } \\
\text { concepts }\end{array}$ & $\begin{array}{c}1,2,3,4 \\
5\end{array}$ & $\begin{array}{l}\text { 1. Interpreting the meaning of a mathematical concept as a } \\
\text { whole correctly and completely } \\
\text { 2. Correctly interpret the meaning of mathematical concepts } \\
\text { but the answers given are incomplete } \\
\text { 3. Correctly interpret the meaning of a mathematical concept } \\
\text { but the answer is wrong } \\
\text { 4. Interpreting the meaning is not a mathematical concept } \\
\text { 5. Wrong answer or no answer }\end{array}$ & $\begin{array}{l}2 \\
1 \\
0 \\
\end{array}$ \\
\hline $\begin{array}{l}\text { Summing up } \\
\text { the solutions } \\
\text { to the } \\
\text { problems } \\
\text { given }\end{array}$ & $\begin{array}{c}1,2,3,4 \\
5\end{array}$ & $\begin{array}{l}\text { 1. Summing up the overall solution to the problem given } \\
\text { correctly and completely } \\
\text { 2. Conclude the solution to the problem given correctly but } \\
\text { the answer is incomplete } \\
\text { 3. Summing up the solution to the problem given correctly } \\
\text { but the answer is wrong } \\
\text { 4. Summarize the solutions to the problems given without } \\
\text { being based on relevant mathematical concepts } \\
\text { 5. Wrong answer or no answer }\end{array}$ & $\begin{array}{l}4 \\
3 \\
2 \\
1 \\
1 \\
0\end{array}$ \\
\hline
\end{tabular}

In this study, the design concept used in designing learning consists of two main stages, namely the exploration and design stages, with the following Figure 1.

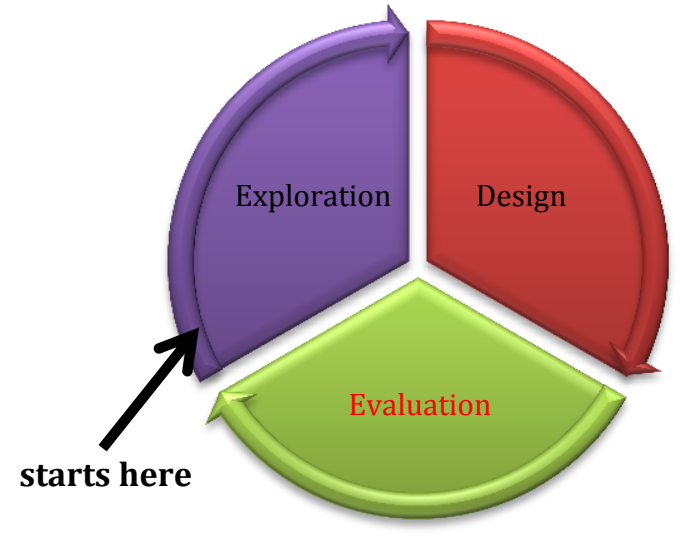

Figure 1. Learning Design Process 
1. The first stage is exploration where the main activity is to identify and examine information related to learning conditions, including students (Diningrat, 2019). In other words, researchers have the main task of collecting and identifying information related to student characteristics, environment, material and learning objectives, which in turn will lead researchers to choose methods that suit student needs.

2. The second stage is designing where the main activity is mapping the information obtained in the exploration stage about the objectives, processes, learning materials using existing pedagogical models and also considering the pedagogical model to be chosen, so that it can be used as consideration in determining the learning method according to student needs (Diningrat, 2019). In other words, this stage requires researchers to produce effective learning methods through the analysis of the results of exploration of pedagogic models or learning theories that can produce specific learning methods and be taken into consideration in choosing learning technologies that can be evaluated at a later stage.

3. The following stage which will be done as a research sustainability, that is the evaluation stage. Evaluation where the main activity is to determine the objectives, expected results and how to evaluate the design of learning methods, combining formative evaluation with a revision cycle that results in the effectiveness of the results of applying learning (Diningrat, 2019). In other words, researchers must be able to apply good decision-making skills by considering factors related to the learning context.

\section{RESULT AND DISCUSSIONS}

Based on some literature that was collected and analyzed the data, results, and discussions were obtained related to the technology-integrated local wisdom-based learning design on extrapolation abilities, namely as follows.

\section{Extrapolation Ability}

Extrapolation ability is the ability to predict or provide an overview of things based on trends that appear in data in the form of consequences, implications, and consequences based on motives and patterns in the data (Suhaesa et al., 2018). The ability to extrapolate according to Harti, Suprapta \& Ikbal (2018) is a person's ability to conclude and state more explicitly a form of graphs, data, predict the consequences of actions depicted from a communication, sensitive or sensitive to factors that might make predictions accurate. Operational verbs that can be used to measure this ability are calculating, guessing, concluding, predicting, differentiating, determining, and filling (Yanti, Nahwiyah \& Mailani, 2018). Extrapolation ability is the highest level of understanding of mathematical concepts, including estimates and predictions based on in a thought, a description of the condition of information, and includes making conclusions with consequences that are in accordance with the third cognitive level of information, namely the application that uses or applies a material that has been studied into a new situation in the form of ideas, theories or technical instructions (Jelatu, Sariyasa \& Ardana, 2018).

Based on some of the opinions above, it can be concluded that extrapolation ability is the ability to predict a trend through mathematical calculations, to be able to apply a concept that has been learned to a new situation in the form of an idea. The extrapolation ability indicators that will be used in this study include the ability to predict trends that will occur, interpret the meaning of mathematical concepts, and conclude solutions to the problems given. The following is a scoring rubric table used for each indicator of extrapolation ability. 


\section{Technology Integrated Local Wisdom}

\section{a. Maddawa-dawa}

Maddawa-dawa is a form of friendship between people to strengthen familiarity with family and society. In practice, this maddawa-dawa must be done collectively or collectively in society. Because its implementation collectively can be meaningful as a medium of communication between family and relatives or a medium to stay in touch and increase integration between people (Rusli, 2015). Maddawa-dawa in the learning process can be interpreted as the apperception stage, namely the teacher's activities to connect the previous learning material with the material to be taught to provide instructions to students what material to learn at that time.

The android application that can be used at the Maddawa-dawa phase is application group maker. This application will assist the teacher in dividing students into groups randomly, namely by simply entering the name of the student (small scale) or student absent number (large scale). The following is an overview of the application group maker.

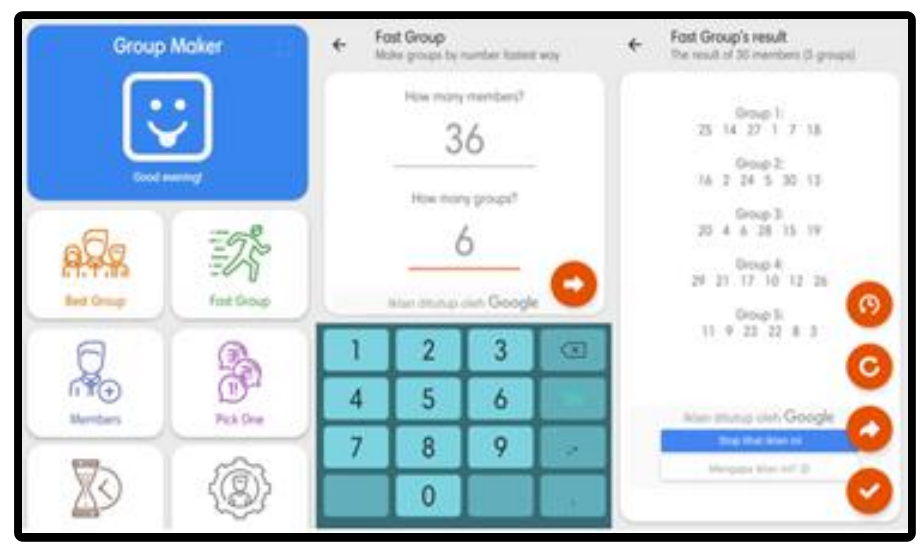

Figure 2. Group Maker Application

\section{b. Mammanu-manu}

Mammanu-manu is the process of seeking further information about the prospective bride, especially about her status, whether someone has proposed or not, or whether the person has been arranged a marriage with another (Tang, 2017). Mammanu-manu in the learning process can be interpreted as the investigative stage, namely learning activities that give students the possibility to develop their understanding through various activities and correct results according to the development they are going through.

Android applications that can be used at the Mammanu-manu phase are applications lucky wheel and mind mapping. The application is a lucky wheel used in determining students who will investigate other groups, then the results of the investigation will be entered into the application mind mapping which will make it easier for students to determine the right solution based on some data. The following is an overview of the application lucky wheel and mind mapping. 


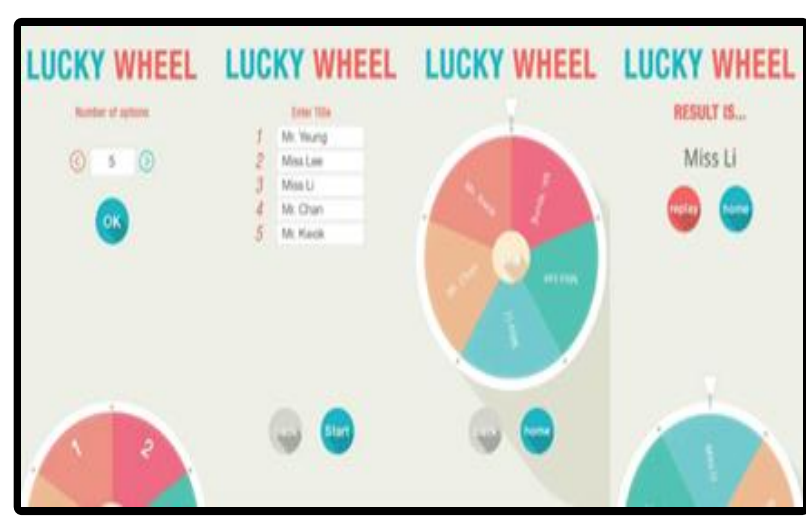

Figure 3. Lucky Wheel Application

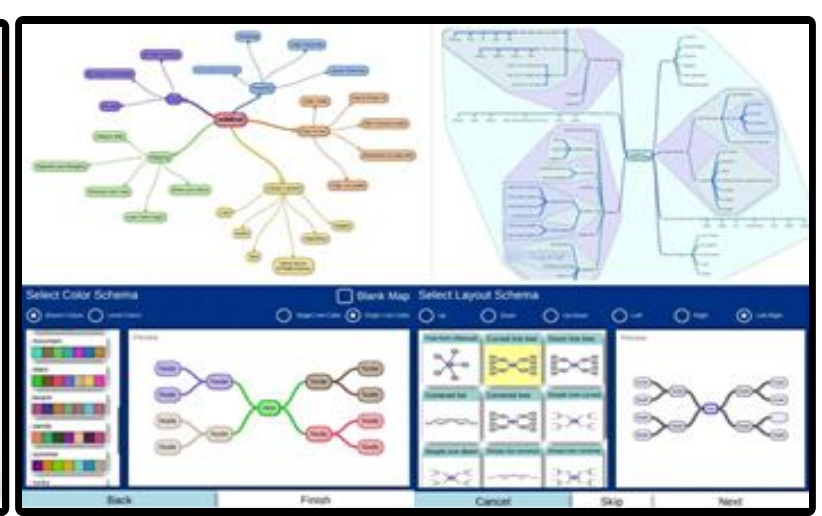

Figure 4. Mind Mapping Application

\section{c. Mappettuada}

Mappettuada is the process of making the final agreement from several previous activities (Zulkhaeriyah, 2018). In the tradition Mappettuada, several performances appear through verbal and non-verbal communication between communities. Verbal communication is a communication process used by language and the spoken words. Nonverbal communication is the delivery of messages without words and is reflected in body language, symbols, and verbal intonation. In the mappetuada tradition, this communication will appear to complement the formality of this tradition (Ansar, 2016). Mappettuada in the learning process can be used as a decision-making stage, namely the process of systematically selecting the best alternative from several alternatives to be used as a way of solving problems.

To make it easier for students to make decisions from several options, the application is used pro \& cons. This application will display several choices and the final agreement from students so that the decision-making process can be easily carried out without taking a lot of time. An overview of the application can be seen as follows.

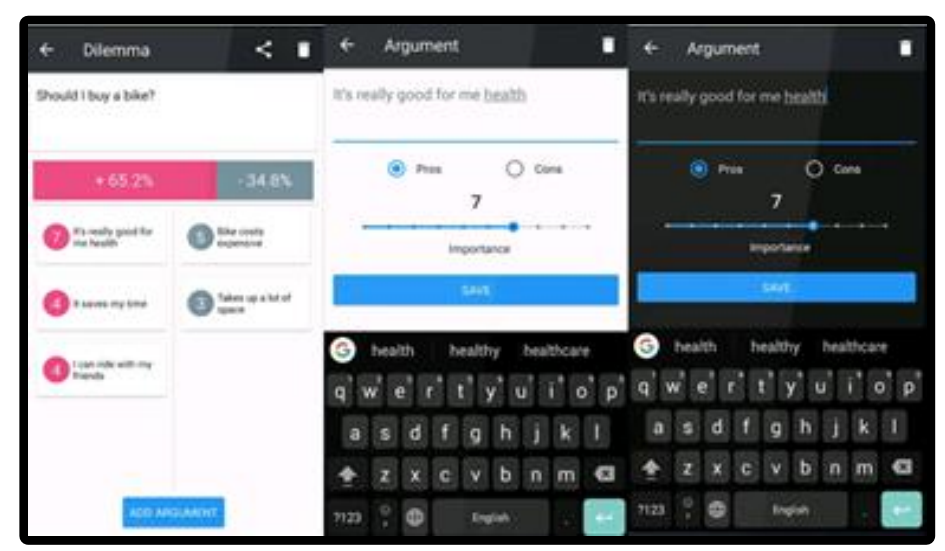

Figure 5. Pro \& Cons Application

\section{Learning Design}

The learning process based on local wisdom integrated technology emphasizes the traditions of the Bugis-Makassar Maddawa-dawa, Mammanu-manu, Mappettuada tribes. The application of the Bugis-Makassar Maddawa-dawa, Mammanu-manu, Mappettuada tribal traditions in the learning process shows the stages of the learning process from beginning to end, namely starting with the Maddawa-dawa stage to the stage Mappettuada. The learning process by integrating the tradition Maddawa-dawa can make it easier for students to learn mathematics, where the material taught will be connected to real-world concepts that are 
easily understood by students so that students' ability to predict future trends can be improved. Through the integration of the tradition Mammanu-manu, the learning process will not seem passive, where each student is actively seeking to know the truth of the problem given. This can help students interpret (interpret) the meaning of mathematical concepts easily. The stage Mappettuada can train students in concluding the right solution to the given problem.

The following is a technology-integrated local wisdom-based learning design for extrapolation abilities.

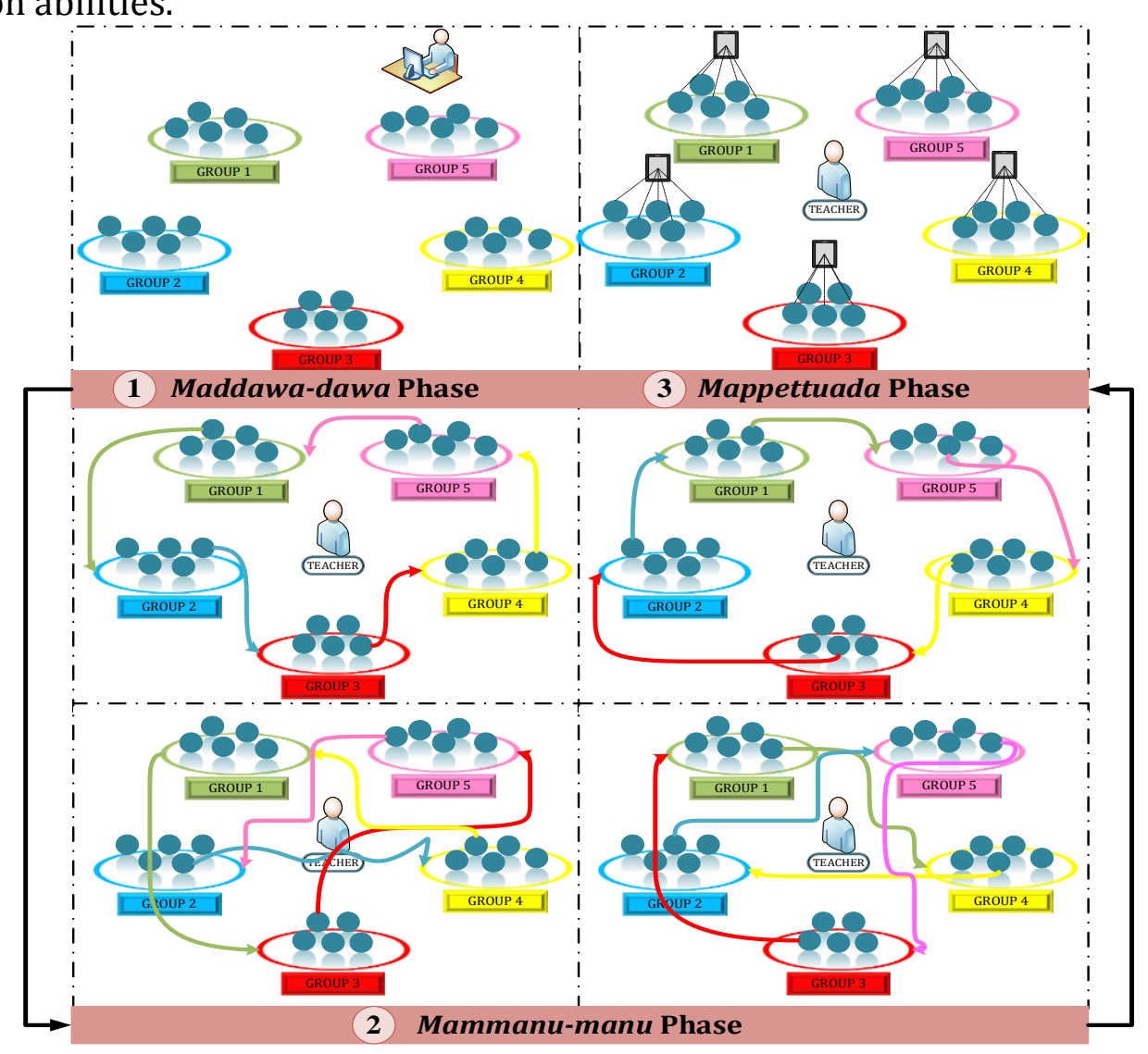

Figure 6. Learning Stages

Based on the Figure 6 above, it appears that the teacher in this case acts as a facilitator and the students play an active role in solving the problems given. The teacher and student activities can be seen in the reaction principle Table 2 below.

Table 2. Reaction Principle

\begin{tabular}{|c|c|c|}
\hline Step & Teacher Reaction & Student Reaction \\
\hline $\begin{array}{l}\text { Maddawa- } \\
\quad \text { dawa }\end{array}$ & $\begin{array}{l}\text { 1. The teacher divides students into } \\
\text { several groups heterogeneously } \\
\text { using the group maker application } \\
\text { 2. The teacher provides materials to } \\
\text { students to be presented more } \\
\text { broadly by connecting real-world } \\
\text { concepts }\end{array}$ & $\begin{array}{l}\text { 1. Students join their group friends } \\
\text { and have discussions } \\
\text { 2. Students listen to the material } \\
\text { presented by the teacher and gather } \\
\text { various information }\end{array}$ \\
\hline $\begin{array}{c}\text { Mammanu } \\
\text { manu' }\end{array}$ & $\begin{array}{l}\text { 1. The teacher divides the assignments } \\
\text { of each student using the lucky wheel } \\
\text { application } \\
\text { 2. The teacher directs students to }\end{array}$ & $\begin{array}{l}\text { 1. Students are responsible for each } \\
\text { assignment given } \\
\text { 2. Students who are group } \\
\text { representatives }\end{array}$ \\
\hline
\end{tabular}




\begin{tabular}{|c|c|c|}
\hline Step & Teacher Reaction & Student Reaction \\
\hline & $\begin{array}{l}\text { investigate other groups } \\
\text { 3. The teacher guides students in } \\
\text { presenting the results of the } \\
\text { investigation into a mind mapping } \\
\text { application }\end{array}$ & $\begin{array}{l}\text { investigations into other groups } \\
\text { 3. Students present the results of the } \\
\text { investigation into a mind mapping } \\
\text { application }\end{array}$ \\
\hline Mappettuada & $\begin{array}{l}\text { 1. The teacher instructs the group } \\
\text { representatives to return to their } \\
\text { respective groups } \\
\text { 2. The teacher guides students in } \\
\text { making decisions based on the } \\
\text { results of investigations using the pro } \\
\text { \& cons application } \\
\text { 3. The teacher invites group } \\
\text { representatives to present the results } \\
\text { of the discussion } \\
\text { 4. The teacher gives awards to the } \\
\text { group that gets the highest results } \\
\text { and is active during the discussion }\end{array}$ & $\begin{array}{l}\text { 1. Students who carry out the } \\
\text { investigation return to their } \\
\text { respective groups } \\
\text { 2. Each group determines a solution to } \\
\text { the problem by making decisions } \\
\text { based on the results of the } \\
\text { investigation } \\
\text { 3. Students who represent their } \\
\text { groups present the results of the } \\
\text { discussion accompanied by strong } \\
\text { arguments } \\
\text { 4. Students from the group who get } \\
\text { the highest results and are active } \\
\text { during the discussion will get the } \\
\text { teacher's appreciation }\end{array}$ \\
\hline
\end{tabular}

\section{CONCLUSION AND SUGGESTIONS}

The learning process based on local wisdom of Maddawa-dawa can make it easier for students to learn mathematics, where the material taught will be connected to real-world concepts that are easily understood by students, so that students' ability to predict future trends can be improved. The application of the Maddawa-dawa phase can be integrated with the group maker application in the group division process. In the Mammanu-manu phase, the learning process will no longer seem passive, where each student is active in finding out the truth of the problem given. This phase can help students interpret (interpretation) the meaning of mathematical concepts by integrating lucky wheel and mind mapping applications. The Mappettuada phase can train students in concluding the right solution of the problems given with the help of pro \& cons applications. This learning design is expected to provide alternative solutions in increasing students' extrapolation abilities, especially in mathematics through a local traditional approach in the learning process.

\section{ACKNOWLEDGEMENT}

Thanks to the Chairman of STKIP Muhammadiyah Bone, the Chairman of the LPPM and his staff, the accompanying lecturers and fellow students who have helped in completing this research.

\section{REFERENCES}

Abdullah, A. S. (2017). Ethnomathematics in Perspective of Sundanese Culture. Journal on Mathematics Education, 8(1), 1-16.

Abiam, P. O., Abonyi, O. S., Ugama, J. O., \& Okafor, G. (2016). Effects of Ethnomathematics-based Instructional Approach on Primary School Pupils' Achievement in Geometry. Journal of Scientific Research \& Reports, 9(2), 1-15. https://doi.org/10.9734/JSRR/2016/19079

Adi, N. H., Fernandes, A. L., \& Hermansyah. (2020). Pengembangan Media Pembelajaran Berbasis Android pada Mata Kuliah Fisika Dasar. Jurnal Ilmu Pendidikan, 3(1), 103-114.

Ansar, F. A. (2016). Islamic Aspects in Mappettuada Tradition for Cross-Cultural Performants. Islamic Aspects in Mappettuada Tradition, 3(2), 182-196. 
Arwanto, Budayasa, I. K., \& Budiarto, M. T. (2018). The Role of Students Intuition in Solving Basic Mathematical Problems in Mathematics Department of Education Faculty of Muhammadiyah Cirebon University. Pancaran Pendidikan, 7(1), 129-134.

Aryani, F., Marzuki, C. C., \& Suryani, I. (2019). Pelatihan Peningkatan Kemampuan Guru dalam Pembelajaran Matematika di Madrasah Ibtidaiyah Se-Kecamatan Tambang Kabupaten Kampar. Journal of Research on Community Engagement (JRCE), 1(1), 14-19.

Asfar, A. M. I. T., Asfar, A. M. I. A., Aspikal, \& Nurwijaya. (2019). Efektivitas Case based Learning (CBL) Disertai Umpan Balik terhadap Pemahaman Konsep Siswa. Histogram: Jurnal Pendidikan Matematika, 3(1), 29-45.

Asfar, A. M. I. T., Asfar, A. M. I. A., Darnawati, \& Darmawan, D. (2019). The Effect of REACE (Relating, Exploring, Applying, Cooperating and Evaluating) Learning Model Toward the Understanding of Mathematics Concept. Journal of Physics: Conference Series, 1-9. https://doi.org/10.1088/1742$6596 / 1028 / 1 / 012145$

Asfar, A. M. I. T., Asfar, A. M. I. A., \& Sartina. (2018). Modifikasi Model Pembelajaran Missouri Mathematics Project (MMP) dengan Model Pembelajaran Explicit Intruction (EI) dalam Meningkatkan Pemahaman Konsep Matematika Siswa. Jurnal AKSARA PUBLIC, 4(2), 23-38.

Asfar, A. M. I. T., Nur, S., \& Asfar, A. M. I. A. (2019). The Improvement of Mathematical Problem-Solving through the Application of Problem Posing \& Solving (PPS) Learning Model. In International Conference on Advanced Multidisciplinary Research (ICAMR 2018) (pp. 362-366). Advances in Social Science, Education and Humanities Research (ASSEHR). https://doi.org/10.2991/icamr18.2019 .89

Aulia, F., Dianti, S. P., Utami, W. B., \& Sina, I. (2019). Ethnomathematics-Based Contextual Learning with Interactive Media to Improve Mathematics Problem Solving. Jurnal Pendidikan MIPA, 20(2), 39-45. https://doi.org/http://dx.doi.org/10.23960/jpmipa/v20i2.pp39-45

Azis, E., Asfar, A. M. I. T., Rianti, M., Hasanuddin, Asfar, A. M. I. A., \& Nur, A. S. A. (2019). Analysis of Validity and Practicality of ROAR (Read, Observe, Auditory, Review) Learning Model. In International Conference on Natural \& Social Sciences (ICONSS 2019) (pp. 398-404). Palopo: Universitas Cokroaminoto Palopo. https://doi.org/https://doi.org/10.30605/iconss.79

Diningrat, S. W. M. (2019). Desain Model Pembelajaran Online sebagai Upaya Memfasilitasi Belajar di Tempat Kerja. Jurnal Pendidikan Terbuka dan Jarak Jauh, 20(1), 17-24.

Effendi, K. N. S. (2018). Penerapan Pembelajaran Advance Organizer dalam Peningkatan Kemampuan Pemahaman Matematis dan Motivasi Belajar Siswa SMK. Prima: Jurnal Pendidikan Matematika, 2(1), 33-48.

Fouze, A. Q., \& Amit, M. (2018). Development of Mathematical Thinking through Integration of Ethnomathematic Folklore Game in Math Instruction. Eurasia Journal of Mathematics, Science and Technology Education, 14(2), 617-630. https://doi.org/10.12973/ejmste/80626

Harti, N. D., Suprapta, \& Ikbal, S. (2018). Penerapan Metode Inquiry Terbimbing dalam Meningkatkan Keterampilan Proses Sains dan Pemahaman Konsep. Jurnal Pendidikan Fisika, 6(2), 89-92.

Hasanah, H., Kusumah, Y. S., \& Priatna, B. A. (2018). Analisis of Students Error in Intuitive Thinking Test. International Conference on Mathematics and Science Education, 3, 785-790.

IEA. (2016). TIMSS 2015 International Result in Mathematics. http://timss2015.org/wpcontent/uploads/filebase/fullpdfs/T15-International-Results-in-Mathematics-Grade-4.pdf.

Diakses pada tanggal 11 Juli 2019

Jelatu, S., Sariyasa, \& Ardana, I. M. (2018). Effect of GeoGebra-Aided REACT Strategy on Understanding of Geometry Concepts. International Journal of Instruction, 11(4), 325-336.

Majid, N. (2019). Methods of Strengthening Children's Characters Through Local Wisdom Mappatulung Bugis as National Identity. International Journal of Theory and Application in Elementary and Secondary School Education (IJTAESE), 1(2), 9-21.

Muhtadi, D., Sukirwan, Warsito, \& Prahmana, R. C. I. (2017). Sundanese Ethnomathematics: Mathematical Activities in Estimating, Measuring and Making Patterns. Journal on Mathematics Education, 8(2), 185-198. https://doi.org/http://dx.doi.org/10.22342/jme.8.2.4055.185-198

Nugraha, D., \& Octavianah, D. (2020). Diskursus Literasi Abad 21 di Indonesia. JPE (Jurnal Pendidikan Edutama), 7(1), 107-126.

Nur, A. S. A., Asfar, A. M. I. T., Ruhni, \& Nurliah, A. (2019). Building Students' Analysis through the 
Application of GOLD (Guided, Organizing, Leaflet, Discovery) Models with Lontara Bilingual Applications based on Android. In International Conference on Advanced Multidisciplinary Research (ICAMR 2018) (pp. 233-236). Advances in Social Science, Education and Humanities Research (ASSEHR). https://doi.org/10.2991/icamr-18.2019.58

Nuraini, L. (2018). Integrasi Nilai Kearifan Lokal dalam Pembelajara Matematika SD/MI Kurikulum 2013. Jurnal Pendidikan Matematika, 1(2), 1-17.

Nurdiawan, R., Maryam, M. S., Lutfia, L., Hermawan, W., \& Hidayat, W. (2019). Analisis Kemampuan Pemahaman Matematis terhadap Prokrastinasi Akademik Siswa dalam Matematika. Journal On Education, 01(03), 65-74.

OECD. (2019). PISA 2018 Result: What Students Know and Can Do. http://www.pisa.oecd.org/. Diakses pada tanggal 27 Desember 2019.

Purwanti, D., Zaenuri, \& Asikin, M. (2020). Problem Solving Ability in the Learning Model of ProblemBased Learning based on Ethnomathematics. Journal of Primary Education, 10(1), 113-120.

Rahayu, Y., \& Pujiastuti, H. (2018). Analisis Kemampuan Pemahaman Matematis Siswa SMP pada Materi Himpunan: Studi Kasus di SMP Negeri 1 Cibadak. Pasundan Journal of Research in Mathematics Learning and Education, 3(2), 93-102.

Resta, E. L., \& Munawaroh. (2018). Kemampuan Pemahaman Matematis Siswa pada Materi Segiempat. Jurnal Pendidikan Tambusai, 2(6), 1710-1718.

Rohaeti, E. E., \& Bernard, M. (2018). The Students' Mathematical Understanding Ability Through Scientific-Assisted Approach of Geogebra Software. Journal of Mathematics Education, 7(2), 165172. https://doi.org/10.22460/infinity.v7i2.p165-172

Rosidah, C., Sudarti, \& Maryani. (2018). Pengaruh Model Process Oriented Guided Inquiry Learning (POGIL) dengan Media Kartu Masalah terhadap Pemahaman Konsep dan Aktivitas Belajar Siswa pada Materi Momentum dan Impuls di SMA. Jurnal Pembelajaran Fisika, 7(1), 30-37.

Rusli, S. (2015). Maddawa-dawa sebagai Interaksi Sosial dalam Pra Acara Pernikahan. Universitas Hasanuddin.

Suhaesa, A. A., Andayani, Y., Muti'ah, M., \& Anwar, Y. A. S. (2018). Pengaruh Model Pembelajaran Predict Observe Explain (POE) terhadap Pemahaman Konsep Siswa Materi Kesetimbangan Kelarutan Kelas XI MIA SMAN 2 Labuapi Tahun Ajaran 2017/2018. Chemistry Education Practice, $1(2), 27-35$.

Suhardi, A. (2018). Pengaruh Penggunaan Mind Map terhadap Pemahaman Konsep Pendidikan Agama Islam bagi Mahasiswa IAIN Jember. Indonesian Journal of Islamic Teaching, 1(1), 29-44.

Sutisna, A. P., Maulana, \& Subarjah, H. (2016). Meningkatkan Pemahaman Matematis melalui Pendekatan Tematik dengan RME. Jurnal Pena Ilmiah, 1(1), 31-40.

Syarifah, L. L. (2017). Analisis Kemampuan Pemahaman Matematis pada Mata Kuliah Pembelajaran Matematika SMA II. Jurnal Penelitian Dan Pengabdian Masyarakat (JPPM), 10(2), 57-71.

Tang, M. (2017). Mahar in Bugis Traditional Marriage Review from the Islamic Law Perspective. Jurnal Bimas Islam, 10(III), 539-564.

Yanti, I. N., Nahwiyah, S., \& Mailani, I. (2018). Penerapan Strategi Prediction Guide untuk Meningkatkan Pemahaman Belajar Siswa pada Mata Pelajaran PAI. Jurnal Pendidikan Agama Islam, 5(1), 26-35.

Yanuarti, S. (2018). Penerapan Pembelajaran Berbasis Predict Observe Explain (POE) pada Pembelajaran Geometri di Kelas X SMA Negeri 13 Palembang. Jurnal Pendidikan Matematika, 12(1), 71-78.

Zakiy, M. A., Syazali, M., \& Farida. (2018). Pengembangan Media Android dalam Pembelajaran Matematika. Journals of Mathematics Education, 1(2), 87-96.

Zulkhaeriyah. (2018). The Discursive Interaction Between Representative Man and Woman in Mappettu Ada Marriage Proposal in Buginese Society. Jurnal Adabiyah, 18(1), 17-30. 